\title{
An Investigation of Cognizance and Approval of Green Advertising by Adolescents in Lucknow City
}

\author{
Dr. Shikha Tripathi \\ Research Scholar, Department of Rural Management (School for Management Studies) Babasaheb Bhimrao \\ Ambedkar University (A Central University), Lucknow, India
}

Article Info

Volume 8, Issue 5

Page Number : 258-264

Publication Issue :

September-October-2021

Article History

Accepted : 10 Oct 2021

Published: 19 Oct 2021

\section{ABSTRACT}

Today the major concern in the world is the environment. Corporate and government is trying to create awareness about the green environment among young consumers by using various tools. One of the important tools used to create awareness about the green environment is green advertising. The study is conducted with two objectives. The first objective of the study is to explore the awareness about green advertising among young consumers of Lucknow city and the second objective is to analyze the impact of green advertising on the behavior of young consumers in Lucknow city. The literature was collected using different databases such as EBSCO and Jstor. The sample size determined for the study is 384 respondents using the formula of an infinite population. Only 223 responses were received out of the targeted sample size of 384 respondents. The primary data collected using a structured questionnaire. The questionnaire was filled using convenience sampling. The statistical tool used for the analysis is descriptive statistics and one-way ANOVA. The results indicate that young consumers are aware of the green advertising in Lucknow city and green advertising has a significant impact on the behavior of young consumers of Lucknow City.

Keywords : Green Advertising, Green Awareness, Ecological Awareness, Environmental Advertising, Environmental Issues.

\section{INTRODUCTION}

Environmental issues are a major concern for the world today. The corporates have focused on going green as part of corporate social responsibility. They are trying to attract their consumers to follow green initiatives through different ways like the use of televisions, FM, internet, schemes, discounts, etc. One of the methods of creating awareness about the environment is advertising, which is most commonly used by the corporates.

"Advertising is concerned as the most important tool for promotion by marketers as it attracts the consumer's attention towards the in-depth knowledge of the product specification and attributes." (Buda and Zhang, 2000) 
Zinkhan and Carlson (1995) defined "Green Advertising is the appeal that tries to fulfill the consumers' needs and aspirations regarding the environmental concern and the health issues from different perspective including ecosystem, sustainability and pollution-free messages" (Gandhi \& Rao, 2013).

The study is conducted to find out the awareness about green advertising among the consumers of Lucknow city. The study especially focuses on young consumers, the impact of green advertising on their behavior and their level of awareness about green advertising.

\section{LITERATURE REVIEW}

There are many past researches conducted about the attitudes of consumers towards green advertising. Several researchers focussed on the company's motivation to introduce green advertising. (Davis, 1992; Frankel, 1992; Gillespie, 1992; Ottman, 1992, 1998, Haytko \& Matulich, 2008). The study conducted by Frankel (1992) focused that consumers become loyal if the company uses green advertising and products. According to Phillips (1999) and Schlossberg (1992) consumers are ready to pay higher prices to the products which are advertised green or which are green products. The research conducted by Manrai, et al. (1997) states that the image of the company is strengthened by using green advertising.

Leonidas et al. (2011) discussed the relationship of consumers' familiarity with environmental issues and the advertising usefulness. The result of the research focused that participants who are low environmentally involved were found valid in green appeals (Richards 2013).

The study conducted by Mitchell and Ramey (2011) states that the passion of the consumers towards the environment leads consumers' keenness to purchase green. The study indicates that consumers' who are more fanatic towards the environment purchase green products than others. The study conducted by Leonidas et al. (2011) highlights that the gap between the attitudes and purchasing behavior of the consumers is the most exigent feature of green advertising and consumer purchasing patterns.

The study conducted by Nagar (2013) discusses the there is a positive attitude of the consumers towards green advertising imposed trust in the brand. She also found that consumers are loyal to the products advertised green and are willing to pay more for these products.

\section{Objectives of the Study}

The study is conducted to:

- To explore the awareness about green advertising among young consumers in Lucknow city.

- To analyze the impact of green advertising on the behavior of young consumers in Lucknow city.

\section{Research Methodology}

The study is conducted on young consumers of Lucknow city, who are between the age group of 20 years to 30 years. Primary as well as secondary data is collected for the study. Primary data is collected using a structured questionnaire that consists of the questions related to the demographic profile of the young consumers, their awareness and behavior about green advertising. Secondary data was collected from websites, journals, magazines, and newspapers. The data was collected from the malls and public places where the young consumers were easily available. Data was collected from the respondents using Convenience sampling. The sample population 
determined for the data collection is 384 respondents using the formula of an infinite population. The responses were received from 223 respondents which is $58.07 \%$ of the targeted sample size. The statistical techniques used in the study are One-way ANOVA for analyzing the impact of green advertising on the behavior of the respondents and the percentage method is used to explore the awareness of young consumers on green advertising. The data is computed using SPSS 21.0.

\section{RESULTS AND DISCUSSION}

The study is conducted on young consumers in Lucknow city, their awareness about green advertising and the impact of green advertising on their behavior.

Table 1: Age Group

\begin{tabular}{|l|c|c|c|c|}
\hline & Frequency & Percent & $\begin{array}{c}\text { Valid } \\
\text { Percent }\end{array}$ & $\begin{array}{c}\text { Cumulative } \\
\text { Percent }\end{array}$ \\
\hline 20 yrs to 22 yrs & 20 & 9.0 & 9.0 & 9.0 \\
22 yrs to 24 yrs & 92 & 41.3 & 41.3 & 50.2 \\
Valid 24 yrs to 26 yrs & 52 & 23.3 & 23.3 & 73.5 \\
26 yrs to 28 yrs & 28 & 12.6 & 12.6 & 86.1 \\
28 yrs to 30 yrs & 31 & 13.9 & 13.9 & 100.0 \\
Total & 223 & 100.0 & 100.0 & \\
\hline
\end{tabular}

Table 1 indicates the classification of the consumer as per the age group. The study is conducted on the consumers falling in the age group of 20 years to 30 years. It is found that 20 respondents fall in the age group of 20 years to 22 years, 92 respondents in the age group of 22 years to 24 years, 52 respondents in the age group of 24 years to 26 years, 28 respondents in the age group of 26 years to 28 years and 31 respondents in the age group of 28 years to 30 years. It is found that $50.2 \%$ of respondents are found very young.

Table 2: Gender

\begin{tabular}{|c|c|c|c|c|}
\hline & Frequency & Percent & $\begin{array}{c}\text { Valid } \\
\text { Percent }\end{array}$ & $\begin{array}{c}\text { Cumulative } \\
\text { Percent }\end{array}$ \\
\hline Male & 126 & 56.5 & 56.5 & 56.5 \\
Valid Female & 97 & 43.5 & 43.5 & 100.0 \\
Total & 223 & 100.0 & 100.0 & \\
\hline
\end{tabular}

Table 2 represents the gender of the respondents. It is found that the study is conducted on 126 males and 97 females, which contribute to $56.5 \%$ and $43.5 \%$ respectively of the responded population. 
Table 3 : Awareness About Green Advertising

\begin{tabular}{|l|c|c|c|c|}
\hline & Frequency & Percent & Valid Percent & Cumulative Percent \\
\hline Aware & 169 & 75.8 & 75.8 & 75.8 \\
Valid Not Aware & 54 & 24.2 & 24.2 & 100.0 \\
Total & 223 & 100.0 & 100.0 & \\
\hline
\end{tabular}

The consumers were analyzed on their awareness about green advertising which is represented in Table 3. It represents that 169 respondents were aware of the green advertising and 54 respondents were not aware of the green advertising. Therefore it is represented that $75.8 \%$ of the respondents were aware of the green advertising and $24.2 \%$ of the respondents were not aware of the green advertising.

Table 4 : Level of Green Awareness

\begin{tabular}{|l|c|c|c|c|}
\hline & Frequency & Percent & $\begin{array}{c}\text { Valid } \\
\text { Percent }\end{array}$ & $\begin{array}{c}\text { Cumulative } \\
\text { Percent }\end{array}$ \\
\hline Very High & 23 & 10.3 & 10.3 & 10.3 \\
High & 49 & 22.0 & 22.0 & 32.3 \\
Valid Average & 66 & 29.6 & 29.6 & 61.9 \\
Low & 68 & 30.5 & 30.5 & 92.4 \\
Very Low & 17 & 7.6 & 7.6 & 100.0 \\
Total & 223 & 100.0 & 100.0 & \\
\hline
\end{tabular}

The consumers were analyzed on the level of awareness about the green advertising. In Table 4 it is found that the awareness level of consumption is low in the city of Lucknow. It is found that $38.1 \%$ of the consumers fall in low awareness about green advertising.

Table 5 : Behaviour of Consumers towards Green Advertising

(Haytko \& Matulich, 2008)

\begin{tabular}{|l|c|c|c|c|c|}
\hline & $\begin{array}{c}\text { Strongly } \\
\text { Agree }\end{array}$ & Agree & Neutral & Disagree & $\begin{array}{c}\text { Strongly } \\
\text { Disagree }\end{array}$ \\
\hline $\begin{array}{l}\text { Loyalty of Consumers Towards } \\
\text { Products using Green Advertising }\end{array}$ & $\begin{array}{c}36 \\
(16.1 \%)\end{array}$ & $\begin{array}{c}56 \\
(25.1 \%)\end{array}$ & $\begin{array}{c}75 \\
(33.6 \%)\end{array}$ & $\begin{array}{c}36 \\
(16.1 \%)\end{array}$ & $\begin{array}{c}20 \\
(9.0 \%)\end{array}$ \\
\hline Willingness to Pay More Price & 39 & 52 & 31 & 83 & 18 \\
$(17.5 \%)$ & $(23.3 \%)$ & $(13.9 \%)$ & $(37.2 \%)$ & $(8.1 \%)$ \\
\hline $\begin{array}{l}\text { Companies Advertising Green are } \\
\text { Trustworthy }\end{array}$ & $\begin{array}{c}53 \\
(23.8 \%)\end{array}$ & $\begin{array}{c}74 \\
(33.2 \%)\end{array}$ & $\begin{array}{c}35 \\
(15.7 \%)\end{array}$ & $\begin{array}{c}44 \\
(19.7 \%)\end{array}$ & $\begin{array}{c}17 \\
(7.6 \%)\end{array}$ \\
\hline
\end{tabular}




\begin{tabular}{|l|c|c|c|c|c|c|}
\hline $\begin{array}{l}\text { Green Advertising Helps to Solve } \\
\text { Environmental Problems }\end{array}$ & $\begin{array}{c}58 \\
(26.0 \%)\end{array}$ & $\begin{array}{c}50 \\
(22.4 \%)\end{array}$ & $\begin{array}{c}43 \\
(19.3 \%)\end{array}$ & $\begin{array}{c}50 \\
(22.4 \%)\end{array}$ & $\begin{array}{c}22 \\
(9.9 \%)\end{array}$ \\
\hline $\begin{array}{l}\text { Green Advertising is Valuable to } \\
\text { Society }\end{array}$ & $\begin{array}{c}55 \\
(24.7 \%)\end{array}$ & $\begin{array}{c}69 \\
(30.9 \%)\end{array}$ & $\begin{array}{c}37 \\
(16.6 \%)\end{array}$ & $\begin{array}{c}46 \\
(20.6 \%)\end{array}$ & $\begin{array}{c}16 \\
(7.2 \%)\end{array}$ \\
\hline
\end{tabular}

Table 5 represents the determinants of behaviour of consumers towards green advertising. It is found that $41.2 \%$ agree to be loyal to the products using green advertising. 33.6\% of the consumers are neutral towards the products using green advertising and $25.1 \%$ of the consumers disagree to be loyal to the products using green advertising.

The consumers are not willing to pay more prices for the products that use green advertising or are green. $45.3 \%$ of the consumers do not wish to pay more prices for the products that use green advertising and $40.8 \%$ of the consumers are willing to pay the higher price for the products that use green advertising or are green.

Consumers feel that companies that use green advertising are trustworthy, 57\% of the consumers agree that the companies which use green advertising are trustworthy whereas; $27.3 \%$ of the consumers think that the companies using the green advertising are not trustworthy.

$48.4 \%$ of the consumers think green advertising helps to solve environmental issues whereas; $32.3 \%$ of the consumers disagree about green advertising as a tool for solving environmental issues.

$55.6 \%$ of the consumers think that green advertising is valuable to society whereas; $27.8 \%$ of the consumers think that green advertising is not valuable for society.

The above determinants of green advertising provide a mixed view of the consumer's attitude and behavior towards green advertising. It demonstrates that some of the determinants consumers agree with and on some, they disagree with. The study examines the behavior and attitude of the consumers towards the determinants of behavior of the consumers towards green advertising.

Table 6: One-way ANOVA (Haytko \& Matulich, 2008)

\begin{tabular}{|l|c|c|}
\hline & F & Sig. \\
\hline Loyalty of Consumers Towards Products using Green Advertising & 17.223 & $.000^{*}$ \\
\hline Willingness to Pay More Price & 17.481 & $.000^{*}$ \\
\hline Companies Advertising Green are Trustworthy & 13.207 & $.000^{*}$ \\
\hline Green Advertising Helps to Solve Environmental Problems & 13.878 & $.000^{*}$ \\
\hline Green Advertising is Valuable to Society & 17.774 & $.000^{*}$ \\
\hline
\end{tabular}

*Significant at $5 \%$ level of significance 
Table 6 shows the results of the impact of green advertising on the behavior of young consumers. The ANOVA is conducted on the determinants of behavior of consumers towards green advertising. The determinants of behavior of consumers are considered as a predictor and the age group of the consumers is considered as constant. The result of One-way ANOVA is found significant at 5\% level of significance. Taking a view on the results of ANOVA it is found that there is a significant impact of green advertising on the behavior of the consumer.

\section{VI.CONCLUSION}

The study is conducted to explore the awareness of green advertising among the young consumers of Lucknow city. It is concluded that the young consumers in Lucknow city are aware of green advertising. The level of awareness about green advertising among young consumers is also analyzed in which it is concluded that young consumers have low awareness about green advertising.

The second aim of the study is to analyze the impact of green advertising on young consumers in Lucknow city. It is concluded that there is a significant impact of green advertising on young consumers of Lucknow city. The result is concluded using one-way ANOVA.

\section{REFERENCES}

[1]. Buda. R and Zhang. Y. 2000. Consumer product evaluation: the interactive effect of message framing, presentation order, and source credibility. Journal of Product \& Brand Management. 9 (4). 229-242.

[2]. Davis. J J. 1992. Ethics and Environmental Marketing. Journal of Business Ethics. (11). 8187.
[3]. Frankel. C. 1992. Blueprint for Green Marketing. American Demographics. (April). 34-38.

[4]. Gandhi A. \& Rao M. 2013. Green Marketing: Impact of Green Advertising on Consumer Purchase Decision. Advances in Management. 6 (9).

[5]. Gillespie. R J. 1992. Pitfalls and Opportunities for Environmental Marketers. Journal of Business Strategy. (July/August). 14-17.

[6]. Haytko D. L. \& Matulich E. 2008. Green Advertising and Environmentally Responsible Consumer Behaviours: Linkages Examined. Journal of Management and Marketing Research. 1. 2-11.

[7]. Leonidas C., Palihawadana D., Hultman M. 2011. Evaluating the green advertising practices of interna $\neg$ tional firms: a trend analysis. International Marketing Review. 28(1), 6-33.

[8]. Manrai. L. A. Manrai. A. K. Lascu D. N, and Ryans. J. K Jr. 1997. How Green-Claim Strength and Country Disposition Affect Product Evaluation and Company Image. Psychology \& Marketing. August. 14 (5). 511.

[9]. Mitchell L.D. and Ramey W.D. 2011. Look how green I am! an individual-level explanation for green wash $\neg$ ing. The Journal of Applied Business and Economics. 12(6). 40-45.

[10]. Nagar K. 2013. An Empirical Investigation into the Influence of Green Advertising on Brand Loyalty. Journal of Services Research. 13(2). 7294.

[11]. Ottman. J. 1992. Industry's Response to Green Consumerism. Journal of Business Strategy. (July/August). 3-7.

[12]. Ottman. J. 1998. Back-Up Green Programs with Corporate Credibility. Marketing News. 32 (22). 9-10.

[13]. Phillips. L E. 1999. Green Attitude. American Demographics. 21 (4). 46-47.

[14]. Richards L. 2013. Examining Green Advertising and Its Impact on Consumer Skepticism and 
Purchasing Pattern. Elon Journal of Undergraduate Research in Communications. 4 (2). Accessed and retrieved from http://www.researchgate.net/publication/23750 6901_Green_Advertising_and_Environmentall y_Responsible_Consumer_Behaviors_Linkages_ Examined on 25 December 2014.

[15]. Schlossberg H. 1992. Marketers Warned to Heed Message of 'Ecologism'. Marketing News. (March 30). 6.

[16]. Zinkhan. G M. and Carlson L. 1995. Green Advertising and the Reluctant Consumer. Journal of Advertising. (Summer) 16.

\section{Cite this article as :}

Dr. Shikha Tripathi, "An Investigation of Cognizance and Approval of Green Advertising by Adolescents in Lucknow City", International Journal of Scientific Research in Science, Engineering and Technology (IJSRSET), Online ISSN : 2394-4099, Print ISSN : 2395-1990, Volume 8 Issue 5, pp. 258-264, September-October 2021. Available at doi : https://doi.org/10.32628/IJSRSET218530 Journal URL : https://ijsrset.com/IJSRSET218530 